\title{
FAKTOR-FAKTOR YANG BERHUBUNGAN DENGAN KUALITAS MIKROBIOLOGI PADA DEPOT AIR MINUM DI PUSKESMAS PURWOKERTO SELATAN TAHUN 2016
}

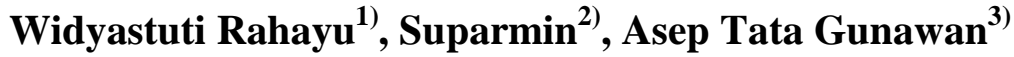 \\ Jurusan Kesehatan Lingkungan, Politeknik Kesehatan Kemenkes Semarang, \\ Jl. Raya Baturaden KM. 12 Purwokerto, Indonesia
}

\begin{abstract}
Abstrak
Pemenuhan kebutuhan air minum masyarakat saat ini sangat bervariasi.Di kota-kota besar untuk memenuhi kebutuhan air minum, sebagian besar masyarakat mengkonsumsi air minum isi ulang yang diproduksi dari Depot Air Minum (DAM). Air minum isi Ulang dari DAM harus memiliki persyaratan yang tercantum dalam Permenkes 492 Tahun 2010 Tentang Persyaratan Kualitas Air Minum. Wilayah Puskesmas Purwokerto Selatan memiliki DAM sebanyak 45. Tujuan penelitian ini adalah untuk mengetahui faktor-faktor yang berhubungan dengan kualitas mikrobiologi pada depot air minum di Wilayah kerja Puskesmas Purwokerto Selatan Tahun 2016. Penelitian ini dilaksanakan di wilayah kerja Puskesmas Purwokerto Selatan. Populasi dalam penelitian ini adalah semua Depot Air Minum di Wilayah Puskesmas Purwokerto Selatan tahun 2016 sebanyak 45 Depot. Penelitian ini menggunakan penelitian total populasi atau Sampling Jenuh. Analisis Data yang digunakan adalah analisis deksriptif statistik dilanjutkan dengan uji Chi Square. Analisa statistik yang digunakan adalah SPSS 17. Kesimpulan dari penelitian ini yaitu faktor-faktor yang berhubungan dengan kualitas mikrobiologi air minum pada DAM di wilayah Puskesmas Purwokerto Selatan pada penelitian ini adalah faktor: tempat ( $p$-value $=0,176)$, peralatan $(p$-value $=0,312)$, perilaku penjamah ( $p$-value $=0,108)$, kualitas filter $(p$-value $=0,108)$, dan jenis alat desinfeksi $(p$-value $=0,103)$.
\end{abstract}

Kata kunci : Air Minum, Depot, Mikrobiologi.

Abstract

Nowadays compliance the need of dringking water is various. For compliance the need of dringking water in the big towns, people consume refill water that produced from water Depot (DAM). Dringking water from DAM must have requirements as stated at Permenkes 492 Tahun 2010 about the requirements of dringking water. The region public health center in south Purwokerto have 45 DAM. The purpose of this research are to determine the factors related to the microbiological quality of drinking water at the Regional Public Health Center in South Purwokerto at 2016. This research was implemented in Public Health in South Purwokerto. The population in this research is all water depots in South Purwokerto Regional Health Center in 2016 as many as 45 Depot. This research uses a total study population or saturated sampling. Data analysis used was descriptive analysis followed by a statistical test Chi Square. The statistical analysis used was SPSS 17. The conclusion of this analysis, factors related to microbiological quality of drinking water in the DAM at The Public Heatlh in South Purwokerto in this research is a factor: place $(p$-value $=0.176)$, equipment $(p$-value $=0.312)$, the behavior of handlers $(p$-value $=$ $0.108)$, quality of the filter ( $p$-value $=0.108)$, and the type of disinfection ( $p$-value $=0.103)$.

Keywords : Depot, Water Consume, Mikrobiology

\section{PENDAhuluan}

Air merupakan salah satu komponen pembentuk lingkungan yang mempunyai peranan cukup besar. Tersedianya air yang berkualitas mengindikasikan lingkungan yang baik. Air merupakan zat yang paling penting setelah udara. Sekitar tiga perempat bagian tubuh kita terdiri dari air dan tidak seorangpun dapat bertahan lebih dari 4-5 hari tanpa air. Menurut Shyamala (2008) air di dalam tubuh manusia berkisar antara 50-70 \% dari seluruh berat badan. Pentingnya air bagi kesehatan dapat dilihat dari jumlah air dalam organ seperti $80 \%$ dari darah adalah air, kehilangan 15\% dari berat badan dapat mengakibatkan kematian (Dvah Survani, 2014, h.168).

1) Email : widya.ntix@gmail.com

2) Email : pakparmin@yahoo.com

3) Email : aseptatagunawan@yahoo.co.id
Pemenuhan kebutuhan air minum masyarakat saat ini sangat bervariasi. Ada masyarakat yang mengambil air minum dari sumber air, air sungai, air tanah baik dengan menggunakan sumur dangkal ataupun dalam dan juga dari air perpipaan yang diproduksi oleh Perusahaan Daerah Air Minum (PDAM) setempat, yang diimasak dahulu sebelum dikonsumsi. Di kota besar, dalam hal pemenuhan kebutuhan air minum masyarakat juga mengkonsumsi Air Minum Dalam Kemasan (AMDK), karena praktis dan dianggap lebih higienis. AMDK diproduksi oleh industri melalui proses otomatis dan disertai dengan pengujian kualitas sebelum diedarkan ke masyarakat. Akan tetapi lama 
kelamaan masyarakat merasa bahwa AMDK semakin mahal, sehingga muncul alternatif lain yaitu air minum yang diproduksi oleh Depot Air Minum (DAM).

Data BPOM (2014) menyatakan bahwa tingginya kasus keracunan penyebab minuman, kemungkinan dapat disebabkan oleh bakteri Coliform, namun belum banyak diungkap dalam penelitian serta datadata yang ditemukan. Air minum merupakan sumber konsumsi utama pada keluarga, yang mana salah satunya yaitu air minum isi ulang karena secara harga tentunya dirasakan manfaat ekonomis bagi keluarga yang tingkat ekonominya kelas menengah ke bawah. Namun, tidak semua Depot Air Minum memberikan jaminan kualitas yang baik terhadap produk yang dihasilkannya (Efri Malisa D.P, 2015, h.2).

Salah satu parameter dalam Air Minum Isi Ulang (AMIU) adalah jumlah bakteri yang terdapat dalam air tersebut, karena apabila bakteri-bakteri tersebut tumbuh dan berkembang dalam tubuh manusia dapat bersifat patogen. Dari sekian banyak jenis bakteri yang terdapat dalam air, bakteri Escherichia coli atau yang lebih sering disebut dengan E. Coli adalah salah satu indikator terhadap air. Permenkes No. 492/MENKES/PER/IV/2010, berisi tentang persyaratan kualitas air minum untuk kandungan maksimum bakteri E.Coli yang diperbolehkan adalah 0 / 100 ml sampel. Air minum yang aman dikonsumsi harus bebas dari kontaminan bakteri E.Coli .

Kualitas air produksi DAM akhir-akhir ini ditengarahi semakin menurun, dengan permasalahan secara umum antara lain pada peralatan DAM yang tidak dilengkapi alat sterilisasi, atau mempunyai daya bunuh rendah terhadap bakteri, atau pengusaha belum mengetahui peralatan DAM yang baik dan cara pemeliharaannya. Hasil penelitian (Athena dkk, 2004) menyatakan bahwa dari 38 DAM di daerah Jakarta, Tangerang dan Bekasi yang diteliti ternyata terdapat 28,9 \% sampel air minum isi ulang yang tercemar oleh bakteri Coliform dan 18,4\% tercemar oleh E. Coli. Keberadaan bakteri Coliform dapat disebabkan oleh beberapa faktor antara lain pencemaran pada air baku, jenis peralatan yang digunakan, pemeliharaan peralatan, penanganan air hasil olahan, sistem transportasi untuk mengangkut air dari sumber air baku ke DAM dan lain-lain.

Berdasarkan hal tersebut diatas peneliti tertarik untuk mengetahui faktor-faktor yang berhubungan dengan kualitas mikrobiologi pada Depot Air Minum di Puskesmas Purwokerto Selatan Tahun 2016. Tujuan penelitian ini adalah untik mengetahui faktorfaktor yang berhubungan dengan kualitas mikrobiologi pada depot air minum di Puskesmas Purwokerto Selatan tahun 2016.

\section{BAHAN DAN METODE}

Penelitian dilakukan dengan pendekatan Explanatory Research. Adapun lokasi penelitian adalah wilayah kerja Puskesmas Purwokerto Selatan. Waktu pelaksanaan penelitian yaitu Desember 2015 sampai dengan Juli 2016. Populasi dalam penelitian ini adalah semua depot air minum di wilayah Puskesmas Purwokerto Selatan tahun 2016 sebanyak 45 depot. Penelitian menggunakan total populasi atau sampling jenuh.

Variabel dalam penelitian ini terdiri dari variabel bebas dan variabel terikat. Bariabel bebas meliputi tempat, peralatan, perilaku penjamah, kualitas filter, ukuran mikrofilter, jenis alat desinfeksi, masa aktif alat desinfeksi, sumber air baku, dan kualitas air baku. Variabel terikat dalam penelitian ini adalah kualitas mikrobilogi air minum yaitu kandungan bakteri E coli dan Coliform.

Data penelitian yang dikumpulkan berupa data umum yang terdiri dari keadaan geografis wilayah Puskesmas Purwokerto Selatan, tahun beroperasi, ijin usaha dan alamat lokasi dari masing-masing depot air minum yang ada di wilayah Puskesmas Purwokerto Selatan. Data khusus berupa sumber air baku, peralatan DAM, kondisi lokasi atau tempat DAM, perilaku penjamah pada DAM, higiene sanitasi di DAM, dan jumlah bakteri Coliform dan E coli pada masing-masing DAM pada air baku dan air minum. Untuk mendapatkan data tersebut peneliti melakukan wawancara, observasi, pengumpulan data serta pengambilan dan pengiriman air baku dan air minum.Instrumen dalam penelitian ini adalah panduan wawancara, check list, dan hasil pemeriksaan laboratorium.

Data yang telah dikumpulkan dianalisis menggunakan software SPSS. Analisis yang dilakukan terdiri dari dua yaitu analisis univariat untuk mengetahui deskrptif dari masing-masinng faktor yang berhubungan dengan kualitas mikrobiologi pada depot air minum, dan analisis bivariat untuk melihat ada tidaknya hubungan antara variabel independen dan variabel dependen. Analisis bivariat dilakukan dengan menggunakan uji Chi Square. Adapun rumus yang digunakan adalah :

$$
\mathrm{X}_{\mathrm{h}}{ }^{2}=\sum_{i=1}^{r} \sum_{j-1}^{k} \frac{\left(O_{i j}-E_{i j}\right)^{2}}{E_{i j}}
$$

$\mathrm{O}_{\mathrm{ij}}=$ jumlah observasi untuk kasus yang dikategorikan baris ke-i pada kolom ke-j.

$\mathrm{E}_{\mathrm{i}}$ =banyak kasus diharapkan di bawah Ho untukdikategorikan dalam baris ke-i pada kolomke-j(Aris Santjaka, 2011, hal 145).

Nilai probabilitas ( $p$ value) : 0,05 Syarat :

- Dikatakan hubungan bermakna secara statistik, jika $p$ value $<0,05$ dan berarti hipotesis diterima.

- Dikatakan hubungan tidak bermakna secara statistik, jika $p$ value $>0,05$ dan berarti hipotesis ditolak.

\section{III.HASIL DAN PEMBAHASAN}

\section{a. Gambaran Umum Daerah Penelitian}


Puskesmas Purwokerto Selatan berada di wilayah Kecamatan Purwokerto Selatan. Wilayah Puskesmas Purwokerto Selatan terdiri dari 7 kelurahan, dengan luas wilayah 13,75 $\mathrm{Km}^{2}$. Berdasarkan data dari Kecamatan Purwokerto Selatan pada akhir tahun 2015, Jumlah penduduk di wilayah Puskesmas Purwokerto Selatan sebanyak 76.559 jiwa yang terdiri dari 37.943 laki-laki (49.56 \%) dan 38.616 perempuan (50.44 $\%)$ tergabung dalam 20.600 rumah tangga / KK.

Puskesmas Purwokerto Selatan memiliki Depot Air Minum (DAM) sebanyak 45 yang tersebar di tujuh (7) kelurahan. Dari 45 DAM tersebut semuanya sudah memiliki ijin dari Dinas Kesehatan dan mendapatkan pengawasan rutin dari petugas sanitarian Puskesmas Purwokerto Selatan. Pengawasan berupa pemantauan rutin setiap bulan untuk sampel bakteriologi dan setahun sekali untuk sampel kimia.Petugas memantau hasil laboratorium bakteriologi dari setiap DAM.Apabila hasil dari sampel positif mengandung bakteri E.Coli maka petugas memberikan pembinaan kepada pemilik DAM.

Peneliti melakukan penyebaran kuesioner sebanyak 45 kuesioner yang dibagikan kepada 45 DAM. Hasil penelitian mengenai karakteristik DAM dapat dilihat pada tabel 1.

\begin{tabular}{|c|c|c|c|c|c|c|}
\hline & $\begin{array}{c}\text { Kepemilika } \\
\text { n SITU }\end{array}$ & $\begin{array}{l}\text { Prosentas } \\
\text { e (\%) }\end{array}$ & $\begin{array}{c}\text { Surat } \\
\text { Jamina } \\
\text { n Pasok } \\
\text { Air } \\
\text { Baku }\end{array}$ & $\begin{array}{c}\text { Prosentas } \\
\text { e (\%) }\end{array}$ & $\begin{array}{c}\text { Hasil } \\
\text { Lab } \\
\text { Air } \\
\text { Minu } \\
\text { m }\end{array}$ & $\begin{array}{c}\text { Prosentas } \\
\text { e (\%) }\end{array}$ \\
\hline $\begin{array}{c}\text { TIDA } \\
\mathbf{K} \\
\end{array}$ & 42 & 93,33 \% & 16 & $35,55 \%$ & 0 & $0 \%$ \\
\hline YA & 3 & $6,67 \%$ & 29 & $64,45 \%$ & 45 & $100 \%$ \\
\hline Total & 45 & $100 \%$ & 45 & $100 \%$ & 45 & $100 \%$ \\
\hline
\end{tabular}

Tabel 1 menunjukkan terdapat 45 Depot Air Minum (DAM) berdasarkan data bulan April 2016. Dilihat dari kepemilikan Surat Ijin Tempat Usaha (SITU) hanya terdapat 3 DAM (6,67\%) yang telah memiliki SITU sedangkan sisanya belum memiliki SITU. Hal ini menggambarkan bahwa rata-rata usaha yang dijalankan belum memiliki ijin usaha dari pemerintah setempat. Sedangkan jika dilihat dari kepemilikan Surat jaminan Pasok Air Baku 29 DAM (64,45\%) sudah memiliki Surat Jaminan Pasok Air Baku, sedangkan sisanya belum. Dari 45 Sampel DAM semuanya (100\%) telah memiliki Hasil Laboratorium Air Minum.

b. Hubungan antara Tempat dengan Kualitas Mikrobiologi Air Minum pada DAM

Hasil analisis hubungan antara tempat dengan kualitas mikrobiologi air minum pada DAM dapat dilihat pada table 2 berikut ini.

Tabel 2. Tabulasi Silang Hubungan antara Tempat dengan Kualitas MikrobiologiAir Minum pada DAM

Faktor

Kualitas mikrobiologis air minum

Tidak Tidak
memenuhi memenuhi

\begin{tabular}{|c|c|c|c|c|c|}
\hline & & & syarat & syarat & \\
\hline \multirow{4}{*}{ Гempa } & Tidak & Jumlah & 8 & 25 & 33 \\
\hline & $\begin{array}{l}\text { memenuh } \\
\text { syarat }\end{array}$ & $\begin{array}{l}\text { Prosentas } \\
\%)\end{array}$ & $24.2 \%$ & $75.8 \%$ & $100.0^{\circ}$ \\
\hline & & Jumlah & 1 & 11 & 12 \\
\hline & $\begin{array}{l}\text { Memenul } \\
\text { syarat }\end{array}$ & $\begin{array}{l}\text { Prosentas } \\
\%)\end{array}$ & $8.3 \%$ & $91.7 \%$ & $100.0^{\circ}$ \\
\hline \multirow[b]{2}{*}{ Total } & & Jumlah & 9 & 36 & 45 \\
\hline & & $\begin{array}{l}\text { Prosentas } \\
\text { (\%) }\end{array}$ & $20.0 \%$ & $80.0 \%$ & $100.0^{\circ}$ \\
\hline
\end{tabular}

Nilai $\boldsymbol{p}$-value $=\mathbf{0 , 4 0 7}$
Tempat Depot Air Minum yang diteliti menunjukkan hasil ada hubungan antara tempat dengan kualitas mikrobiologis air minum yang dihasilkan DAM yang ditunjukan dengan nilai $p$ valuePhi-Cramer's $V$ lebih besar dari 0,05 yaitu 0,176 . Meskipun hubungan antara kedua variabel ini lemah namun perlu diperhatikan syarat-syarat tempat yang harus disediakan untuk mendirikan Depot Air Minum sesuai dengan peraturan yang berlaku (Keputusan Menteri Perindustrian dan Perdagangan RI Nomor 651/MPP/Kep/10/2004).

Hal ini tidak sama dengan penelitian yang dilakukan oleh Abriandy (2016) yang menyatakan bahwa variabel higiene lingkungan menunjukan tidak ada hubungan secara statistik dengan kualitas mikrobiologis air minum isi ulang, hal ini ditunjukan dengan nilai dari $p$-value $=0,0991$ (95\%CI 0,856-4,620), walaupun nilai PR 1,989 yang menunjukan prevalensi kualitas mikrobiologis air minum isi ulang pada DAM yang tidak memenuhi syarat higiene lingkungan akan meningkat 1,989 kali dibanding dengan DAM yang memenuhi persyaratan variabel higiene lingkungan.

c. Hubungan Peralatan dengan Kualitas Mikrobiologi Air Minum pada Depot Air Minum

Berdasarkan hasil analisis Bivariat menggunakan analisis uji Chi Square terhadap faktor yang diduga berhubungan dengan kuailtas mikrobiologis air minum DAM diperoleh hasil bahwa faktor peralatan berhubungan dengan kualitas mikrobiologi air minum DAM di wilayah Puskesmas Purwokerto Selatan yang diketahui dengan nilai p-valuePhi Cramer's V sebesar 0,312 atau lebih kecil dari 0,5. Kekuatan hubungan antara kedua variabel ini lemah.

Tabel 3. Tabulasi Silang Hubungan antara Peralatan dengan Kualitas Mikrobiologi Air Minum pada DAM

\begin{tabular}{|c|c|c|}
\hline \multirow{2}{*}{ Faktor } & $\begin{array}{c}\text { Kualitas } \\
\text { mikrobiologis air } \\
\text { minum }\end{array}$ & \multirow{2}{*}{ Total } \\
\hline & $\begin{array}{c}\text { Tidak Tidak } \\
\text { memenulmemenul } \\
\text { i syarat i syarat }\end{array}$ & \\
\hline PeralataГidak & 2 & 3 \\
\hline memenuhProsentas & S $\quad 66.7 \%$ & 100.0 \\
\hline
\end{tabular}




\begin{tabular}{|c|c|c|c|c|c|}
\hline & syarat & ב (\%) & & & $\%$ \\
\hline & & Jumlah & 7 & 35 & 42 \\
\hline & i syarat & $\begin{array}{l}\text { Prosentas } \\
\text { ح (\%) }\end{array}$ & $16.7 \%$ & $83.3 \%$ & $\begin{array}{r}100.0 \\
\% \\
\end{array}$ \\
\hline \multirow[b]{2}{*}{ Total } & & Jumlah & 9 & 36 & 45 \\
\hline & & $\begin{array}{l}\text { Prosentas } \\
\text { ə (\%) }\end{array}$ & $20.0 \%$ & $80.0 \%$ & $\begin{array}{r}100.0 \\
\% \\
\end{array}$ \\
\hline
\end{tabular}

Faktor peralatan yang memiliki kekuatan hubungan lemah dengan kualitas mikrobiologi air minum DAM perlu mendapatkan perhatian dari pemilik atau pengusaha DAM, karena apabila dilihat secara proporsional faktor peralatan berhubungan dengan kualitas mikrobiologi air minum DAM yang dapat dilihat pada tabel 4.12. Hasil analisis crosstab masing-masing faktor yang berhubungan dengan kualitas mikrobiologi air minum, yaitu 66,7\% DAM yang tidak memenuhi persyaratan peralatan, hasil analisa laboratorium menunjukkan air minum positif mengandung bakteri E. Coli dan Coliform.

\section{d. Hubungan Perilaku Penjamah dengan Kualitas Mikrobiologi Air Minum pada Depot Air Minum}

Hasil penelitian menunjukkan bahwa perilaku penjamah berhubungan dengan kualitas mikrobiologis air minum yang dihasilkan dengan nilai p-value Phi Cramer's $V$ sebesar 0,108. Meskipun kekuatan hubungan kedua variabel ini lemah namun perlu mendapat perhatian yang serius karena berdasarkan hasil pengamatan di lokasi DAM 95,6\% penjamah tidak memenuhi syarat, yaitu tidak mencuci tangan sebelum mengisi galon dan melayani konsumen, selain itu sebagian besar penjamah merokok sambil bekerja. Hal ini tidak diperbolehkan dalam Peraturan Menteri Kesehatan Republik Indonesia Nomor 43 Tahun 2014 Pasal 3 yang mengatur tentang persyaratan Hygiene Sanitasi Depot Air Minum. Tabel 4. Tabulasi Silang Hubungan antara Perilaku Penjamah dengan Kualitas Mikrobiologi Air Minum pada DAM

\begin{tabular}{|c|c|c|c|c|}
\hline & \multirow{2}{*}{ Faktor } & \multicolumn{2}{|c|}{$\begin{array}{c}\text { Kualitas } \\
\text { mikrobiologis air } \\
\text { minum } \\
\end{array}$} & \multirow{2}{*}{ Total } \\
\hline & & $\begin{array}{c}\text { Tidak } \\
\text { memenuh } \\
\text { i syarat }\end{array}$ & $\begin{array}{c}\text { Tidak } \\
\text { nemenuh } \\
\text { syarat }\end{array}$ & \\
\hline \multirow{4}{*}{$\begin{array}{l}\text { Perilaku } \\
\text { Penjama } \\
\text { h }\end{array}$} & Tidak Jumlah & 9 & 34 & 43 \\
\hline & $\begin{array}{l}\text { memenuHrosentas } \\
\text { i syarat ב (\%) }\end{array}$ & $20.9 \%$ & $79.1 \%$ & $\begin{array}{c}100.0 \\
\%\end{array}$ \\
\hline & Jumlah & 0 & 2 & 2 \\
\hline & $\begin{array}{l}\text { Memenu } \\
\text { i syarat Prosentas } \\
\text { ə (\%) }\end{array}$ & $.0 \%$ & $\begin{array}{c}100.0 \\
\%\end{array}$ & $\begin{array}{c}100.0 \\
\%\end{array}$ \\
\hline \multirow[b]{2}{*}{ Total } & Jumlah & 9 & 36 & 45 \\
\hline & $\begin{array}{l}\text { Prosentas } \\
\text { ح (\%) }\end{array}$ & $20.0 \%$ & $80.0 \%$ & $\begin{array}{c}100.0 \\
\%\end{array}$ \\
\hline
\end{tabular}

Hasil penelitian ini berbeda dengan penelitian yang dilakukan oleh Abriandy (2016) yang menyatakan bahwa secara statistik tidak ada hubungan antara perilaku higiene penjamah dengan kualitas mikrobiologis air minum isi ulang, yang ditunjukan dari nilai $p$-value $=1,000$, karena ada nilai didalam sel yang 0 , maka analisis secara bivariat tidak dapat dialakukan untuk mementukan nilai CI dan PR dari variabel perilaku higiene penjamah.

e. Hubungan Kualitas Filter dengan Kualitas Mikrobiologi Air Minum pada Depot Air Minum

Kualitas filter pada penelitian ini memiliki hubungan yang lemah dengan kualitas mikrobiologis Depot Air Minum (nilai $p$-value Phi Cramer's V 0,108). Hal ini disebabkan karena media filter yang digunakan pada masing-masing depot berbeda sehingga setiap media filter yang digunakan juga mempunyai perbedaan kualitas penyaringan. Kualitas filtrasi merupakan salah satu faktor risiko penyebab terjadinya pencemaran mikrobiologi air produk DAMIU (Rahayu dkk. 2013).

Filtrasi pada DAM dilakukan secara bertingkat dari media filter berpori-pori besar ke media filter berpori-pori lebih kecil. Efektifitas filter pada DAMIU tergantung pada kualitas air baku, semakin baik kualitas air baku maka masa pakai filter akan semakin lama, karena daya saring filter tidak terlalu berat dengan kata lain tingkat kejernihan air baku akan mempengaruhi filter, semakin keruh air baku semakin berat kerja filter, sehingga hasil proses penyaringan dapat kurang optimal (Rahayu dkk. 2013).

Tabel 5. Tabulasi Silang Hubungan antara Kualitas Filter dengan Kualitas Mikrobiologi Air Minum pada DAM

\begin{tabular}{|c|c|c|c|}
\hline \multirow{3}{*}{ Faktor } & \multicolumn{2}{|c|}{$\begin{array}{c}\text { Kualitas } \\
\text { mikrobiologis air } \\
\text { minum } \\
\end{array}$} & \multirow{3}{*}{ Total } \\
\hline & \multirow{2}{*}{\multicolumn{2}{|c|}{ 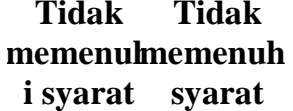 }} & \\
\hline & & & \\
\hline Jumlah & 0 & 2 & 2 \\
\hline memenuhProsentas & & 100.0 & 100.0 \\
\hline \multicolumn{4}{|l|}{ Kualitayarat $2(\%)$} \\
\hline \multirow{2}{*}{$\begin{array}{c}\text {; Filter } \\
\text { i syarat }\end{array}$} & 9 & 34 & 43 \\
\hline & $20.9 \%$ & $79.1 \%$ & $\begin{array}{c}100.0 \\
\%\end{array}$ \\
\hline \multirow[b]{2}{*}{ Total } & 9 & 36 & 45 \\
\hline & $20.0 \%$ & $80.0 \%$ & $\begin{array}{c}100.0 \\
\%\end{array}$ \\
\hline \multicolumn{4}{|l|}{ Nilai $p$-value $=1,000$} \\
\hline \multicolumn{4}{|c|}{$\begin{array}{l}\text { Hasil penelitian ini sama dengan penelitian } \\
\text { ang dilakukan oleh Abriandy (2016) yang } \\
\text { enyatakan bahwa secara statistik variabel } \\
\text { ualitas filter menunjukan adanya hubungan }\end{array}$} \\
\hline
\end{tabular}


dengan kualitas mikrobiologis air minum isi ulang yang ditunjukan dari nilia $p$-value $=0,0304$ (95\%CI 1,006-10,525). Nilai PR 3,255 pada variabel kualitas filter menunjukan prevalensi kualitas mikrobiologis air minum isi ulang pada DAM yang tidak memenuhi syarat kualitas filter akan meningkat 3,255 kali dibanding dengan DAM yang memenuhi persyaratan kualitas filter.

\section{f. Hubungan Ukuran Mikrofilter dengan Kualitas Mikrobiologi Air Minum pada Depot Air Minum \\ Tabel 6.Tabulasi Silang Hubungan antara Ukuran Mikrofilter dengan Kualitas Mikrobiologi Air Minum pada DAM}

\begin{tabular}{|c|c|c|c|c|}
\hline & \multirow{2}{*}{ Faktor } & \multicolumn{2}{|c|}{$\begin{array}{c}\text { Kualitas } \\
\text { mikrobiologis air } \\
\text { minum } \\
\end{array}$} & \multirow{2}{*}{ Total } \\
\hline & & $\begin{array}{r}\text { Tidak } \\
\text { memenu } \\
\text { i syara }\end{array}$ & $\begin{array}{c}\text { Tidak } \\
\text { nemenul } \\
\text { i syarat }\end{array}$ & \\
\hline \multirow{4}{*}{$\begin{array}{l}\text { Ukuran } \\
\text { Mikrofilt } \\
\text { r }\end{array}$} & Iumlah & 8 & 32 & 40 \\
\hline & $\begin{array}{l}\text { memenulProsentas } \\
\text { i syarat } \supseteq(\%)\end{array}$ & $20.0 \%$ & $80.0 \%$ & $\begin{array}{c}100.0 \\
\%\end{array}$ \\
\hline & Jumlah & 1 & 4 & 5 \\
\hline & $\begin{array}{l}\text { Memenu } \\
\text { i syarat } \\
\stackrel{2}{2}(\%)\end{array}$ & $20.0 \%$ & $80.0 \%$ & $\begin{array}{c}100.0 \\
\%\end{array}$ \\
\hline \multirow[b]{2}{*}{ Total } & Jumlah & 9 & 36 & 45 \\
\hline & $\begin{array}{l}\text { Prosentas } \\
\geq(\%)\end{array}$ & $20.0 \%$ & $80.0 \%$ & $\begin{array}{c}100.0 \\
\%\end{array}$ \\
\hline
\end{tabular}

Vilai $\boldsymbol{p}$-value $=\mathbf{1 , 0 0 0}$
Berdasarkan hasil penelitian, dari 45 DAM
terdapat 43 DAM (95,6\%) dikatakan memenuhi persyaratan ukuran mikrofilter, sedangkan 2 lainnya $(4,4 \%)$ tidak memenuhi persyaratan. Pemakaian mikrofilter yang berjenjang tidak dilakukan pada semua DAM. Sebagian besar DAM menggunakan satu jenis ukuran mikrofilter dalam melakukan penyaringan (10 mikron, 5 mikron, 0,5 mikron 0,1 mikron). Hal ini dapat mengakibatkan partikel-partikel halus ataupun bakteri tidak akan tersaring, karena semakin banyak penyaring yang digunakan dengan ukuran yang semakin mengecil akan membantu dalam menyaring partikel lembut (Purwadi, 2003dalam Supriyono, 2004).

Ukuran mikrofilter pada penelitian ini tidak berhubungan dengan kualitas mikrobiologis Depot Air Minum dengan nilai p-value Phi Cramer's $V$ sebesar 0,000. Hal ini sesuai dengan penelitian yang dilakukan oleh Abriandy (2016) yang menyatakan bahwa secara statistik tidak ada hubungan antara ukuran filter dengan kualitas mikrobiologis air minum isi ulang.

Dalam hal penggunaan ukuran mikrofilter petugas sanitarian sudah menganjurkan untuk menggunakan sesuai dengan peraturan yang berlaku yaitu berjenjang dari yang berukuran besar sampai ukuran kecil, namun pengusaha beralasan bahwa ada konsumen yang melakukan komplain tentang rasa air minum yang tidak enak apabila menggunakan mikrofilter secara berjenjang.

g. Hubungan Jenis Alat Desinfeksi dengan Kualitas Mikrobiologi Air Minum pada Depot Air Minum Isi Ulang

Tabel 7.Tabulasi Silang Hubungan antara Jenis Alat Desinfeksi dengan Kualitas Mikrobiologi Air Minum pada DAM

\begin{tabular}{|c|c|c|c|c|}
\hline \multirow{2}{*}{ Fakto } & \multicolumn{3}{|c|}{$\begin{array}{c}\text { Kualitas } \\
\text { mikrobiologis air } \\
\text { minum } \\
\end{array}$} & \multirow{2}{*}{ Total } \\
\hline & & $\begin{array}{c}\text { Tidak } \\
\text { memenuln } \\
\text { syarat }\end{array}$ & $\begin{array}{c}\text { Tidak } \\
\text { nemenuh } \\
\text { syarat }\end{array}$ & \\
\hline \multirow{4}{*}{$\begin{array}{l}\text { Jenis alat } \\
\text { Desinfeks }\end{array}$} & Jumlah & 3 & 8 & 11 \\
\hline & $\begin{array}{l}\text { Prosentas } \\
\%)\end{array}$ & $27.3 \%$ & $72.7 \%$ & $100.0 \%$ \\
\hline & Jumlah & 6 & 28 & 34 \\
\hline & $\begin{array}{l}\text { Prosentas } \\
\%)\end{array}$ & $17.6 \%$ & $82.4 \%$ & $100.0 \%$ \\
\hline \multirow[b]{2}{*}{ Total } & Jumlah & 9 & 36 & 45 \\
\hline & $\begin{array}{l}\text { Prosentas } \\
\%)\end{array}$ & $20.0 \%$ & $80.0 \%$ & $100.0 \%$ \\
\hline
\end{tabular}

\section{Nilai $p$-value $=0,666$}

Jenis alat desinfeksi yang digunakan pada Depot Air Minum yang diteliti adalah jenis UV dan RO. Hasil penelitian menunjukkan ada hubungan antara jenis alat desinfeksi yang digunakan dengan kualitas mikrobiologis air minum yang dihasilkan dengan nilai p-value Phi Cramer's $V$ 0,103. Kekuatan hubungan dua variabel ini lemah.

Pada prinsipnya penggunaan alat desinfeksi dengan UV dan RO bisa diterapkan dalam pengolahan air minum pada DAM, namun harus memperhatikan persyaratan penggunaannya. Misal untuk penggunaan UV harus sesuai dengan debit air dan kecepatan melewati lampu UV, untuk penggunaan RO harus memperhatikan kekeruhan air baku yang digunakan.

Penelitian ini beda dengan penelitian yang dilakukan oleh Abriandy (2016) yang menyatakan bahwa penggunaan desinfektan tidak menunjukan adanya hubungan dengan kualitas mikrobiologis air minum isi ulang, dilihat dari nilai $p$ value $=0,4221$.

h. Hubungan Masa Aktif Alat Desinfeksi dengan Kualitas Mikrobiologi Air Minum pada Depot Air Minum

Hasil pengamatan masa aktif alat desinfeksi tidak bisa dianalisa dengan uji statistik Chi Square karena semua alat desinfeksi masih aktif (tidak kadaluwarsa). Meskipun hasil dari pengamatan masa aktif alat desinfeksi ini tidak bisa dianalisa namun pengusaha perlu memperhatikan periode penggantian alat desinfeksi terutama DAM yang menggunakan alat 
desinfeksi lampu UV. Pengusaha bisa melakukan pemantauan dengan cara mencatat tanggal pembelian lampu UV dan mencatat jumlah volume air minum yang di produksi, sehingga pengusaha dapat memperkirakan kapan harus melakukan penggantian alat desinfeksi (lampu UV) tersebut.

i. Hubungan Jenis dan Sumber Air Baku dengan Kualitas Mikrobiologi Air Minum pada Depot Air Minum Isi Ulang

Berdasarkan hasil analisa bivariat Chi Square diperoleh hasil bahwa nilai p-value Phi Cramer's $V$ sebesar 1,000 sehingga dikatakan tidak ada hubungan yang bermakna secara signifikan antara jenis dan sumber air baku yang digunakan pada Depot Air Minum di wilayah Puskesmas Purwokerto Selatan dengan kualitas mikrobiologi air minum yang dihasilkan DAM. Hal ini sesuai dengan penelitian Abriandy (2016) yang menyatakan bahwa tidak ada hubungan antara sumber air dengan kualitas mikrobiologis air minum isi ulang yang ditunjukan oleh nilai $p$ value sumur $=0,6917$ (95\%CI 0,505-2,790) dan $p$ value mata air=1,0000 (95\%CI 0,168-3,316), tetapi nilai PR variabel sumber air yang berasal dari sumur yaitu 1,18 menunjukan prevalensi kualitas mikrobiologis air minum isi ulang pada DAM yang menggunakan air sumur sebagai sumber air akan meningkat 1,18 kali dibanding dengan DAM yang menggunakan PDAM sebagai sumber airnya.

Tabel 8.Tabulasi Silang Hubungan antara Kualitas Air Baku dengan Kualitas Mikrobiologi Air Minum pada DAM

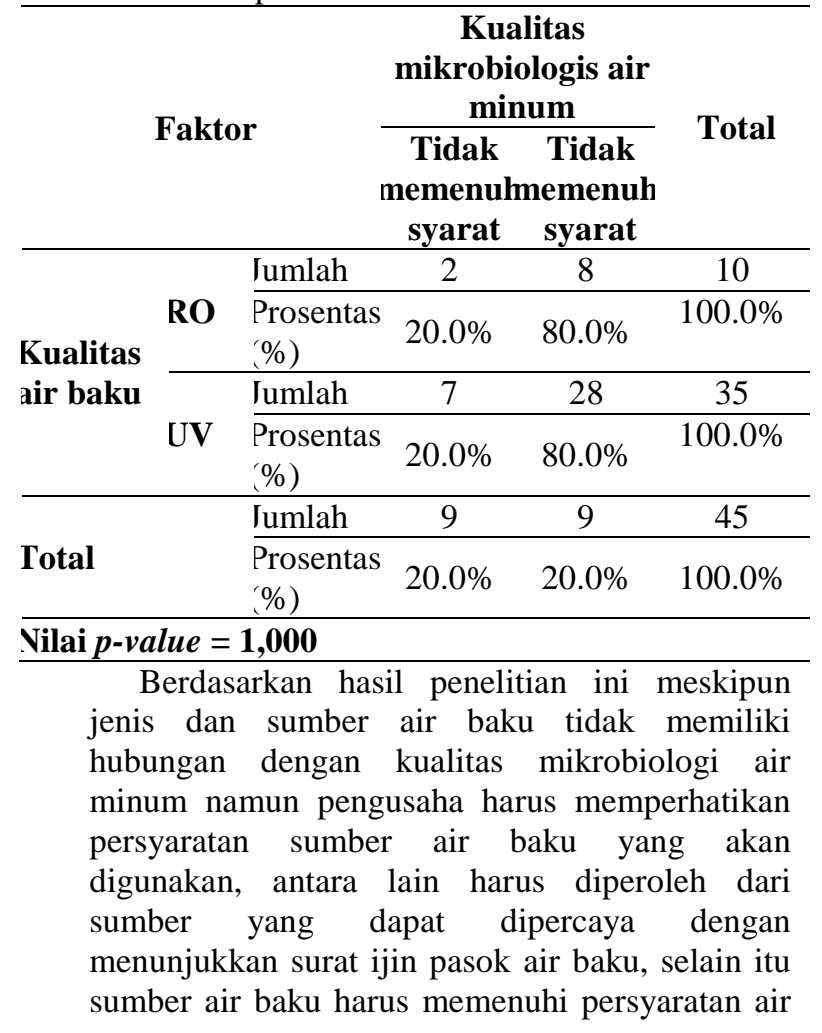

bersih yang tertuang dalam Permenkes 416 Tahun 1990.

Kualitas air baku, semakin baik kualitas air baku maka masa pakai filter akan semakin lama, karena daya saring filter tidak terlalu berat dengan kata lain tingkat kejernihan air baku akan mempengaruhi filter, semakin keruh air baku semakin berat kerja filter, sehingga hasil proses penyaringan dapat kurang optimal (Rahayu dkk. 2013).

\section{j. Kualitas Mikrobiologi Air Minum Isi Ulang}

Hasil pemeriksaan kandungan total Coliform dan E Coli pada air minum yang dihasilkan DAM dapat dilihat pada tabel 4.10.

Tabel 9. Kualitas mikrobiologi air minum pada Depot Air Minum di wilayah kerja Puskesmas Purwokerto Selatan

\begin{tabular}{lccc}
\hline $\begin{array}{c}\text { Kandungan Bakteri Air } \\
\text { Minum }\end{array}$ & $\begin{array}{c}\text { Jumlah } \\
\text { Depot }\end{array}$ & $\begin{array}{c}\text { Prosentase } \\
\text { (\%) }\end{array}$ \\
\hline $\begin{array}{l}\text { Mengandung bakteri } \\
\text { coli dan Coliform }\end{array}$ & 8 & $17,8 \%$ \\
\hline $\begin{array}{l}\text { Tidak mengandung } \\
\text { bakteri E coli maupun } \\
\text { Coliform }\end{array}$ & 37 & $82,2 \%$ \\
\hline
\end{tabular}

Berdasarkan hasil analisis air minum di laboratorium didapatkan hasil bahwa dari 45 DAM terdapat 82,2\% yang memenuhi persyaratan mikrobiologis yaitu bebas dari kandungan bakteri E Coli dan Coliform, sedangkan 17,8\% mengandung kedua bakteri tersebut.Sesuai dengan Peraturan Menteri Kesehatan RI No. 492/MENKES/PER/IV/2010 tentang persyaratan kualitas air minum. Keberadaan jumlah coliform dalam air disebabkan oleh desinfeksi yang tidak sempurna serta pencucian dan pembilasan galon yang rawan pencemaran.(Muh. Navis Mirza, 2014).

\section{IV.KESIMPULAN}

a. Depot Air Minum (DAM) yang memenuhi syarat mikrobiologi air baku sebanyak 36 atau (80\%) dan yang tidak memenuhi syarat sebanyak 9 atau (20\%) .

b. Depot Air Minum DAM yang memenuhi syarat mikrobiologi air minum sebanyak 37 atau $(82,22 \%)$ dan yang tidak memenuhi syarat sebanyak 8 atau $(17,19 \%)$.

c. Faktor-faktor yang berhubungan dengan kualitas mikrobiologi air minum pada DAM di wilayah Puskesmas Purwokerto Selatan pada penelitian ini adalah: tempat $(P$-value $=0,176)$, peralatan $(P$ value $=0,312)$, perilaku penjamah $(P$-value $=$ $0,108)$, kualitas filter $(P$-value $=0,108)$, dan jenis alat desinfeksi $(P$-value $=0,103)$.

d. Ada hubungan antara tempat dengan kualitas mikrobiologi air minum pada DAM dengan nilai p-valuePhi Cramer's V 0,176 pada uji Chi Square. Kekuatan hubungan kedua variabel 
tersebut lemah atau tidak bermakna secara signifikan karena nilai $p$-value $<0,5$.

e. Ada hubungan antara peralatan dengan kualitas mikrobiologi air minum pada DAM dengan nilai p-valuePhi Cramer's V 0,312 pada uji Chi Square. Kekuatan hubungan kedua variabel tersebut lemah atau tidak bermakna secara signifikan karena nilai $p$-value $<0,5$.

f. Ada hubungan antara kualitas mikrofilter dengan kualitas mikrobiologi air minum pada DAM dengan nilai p-valuePhi Cramer's V 0,108 pada uji Chi Square. Kekuatan hubungan kedua variabel tersebut lemah atau tidak bermakna secara signifikan karena nilai $p$-value $<0,5$.

g. Tidak ada hubungan yang bermakna secara signifikan antara ukuran mikrofilter dengan kualitas mikrobiologi air minum pada DAM dengan nilai p-valuePhi Cramer's V 0,000 pada uji Chi Square.

h. Ada hubungan antara jenis alat desinfeksi (RO dan UV) dengan kualitas mikrobiologi air minum pada DAM dengan nilai p-valuePhi Cramer's $V$ 0,103 pada uji Chi Square. Kekuatan hubungan kedua variabel tersebut lemah atau tidak ermakna secara signifikan karena nilai $p$-value $<0,5$.

i. Tidak ada hubungan yang bermakna secara signifikan antara masa aktif alat desinfeksi dengan kualitas mikrobiologi air minum pada DAM. Uji Chi Square tidak bisa dilakukan karena semua alat desinfeksi masih aktif (tidak ada yang kadaluwarsa).

j. Ada hubungan antara perilaku penjamah dengan kualitas mikrobiologi air minum pada DAM dengan nilai p-valuePhi Cramer's V 0,108 pada uji Chi Square. Kekuatan hubungan kedua variabel tersebut lemah atau tidak bermakna secara signifikan karena nilai $p$-value $<0,5$.

k. Tidak ada hubungan yang bermakna secara signifikan antara air baku yang digunakan DAM dengan kualitas mikrobiologi air minum pada DAM dengan nilai p-valuePhi Cramer's V 0,000 pada uji Chi Square.

\section{DAFTAR PUSTAKA}

Abriandy, Harry, 2016, Faktor-faktor yang Berhubungan dengan Kualitas Mikrobiologis Air Minum Isi Ulang pada Depot Air Minum di Kabupaten Banyumas, Tesis, Program Pasca Sarjana, Fakultas Kedokteran, Universitas Gadjah Mada, Yogyakarta.

Aris Santjaka, 2011, Statistik Untuk Penelitian Kesehatan, Muha Media, Yogyakarta, 180 hal.

Athena, Sukar dan Haryono, 2004, Kandungan Bakteri Total Coli dan Escherichia Coli/Fecal Coli Air Minum Dari Depot Air Minum Isi Ulang (DAM) Di Kecamatan Wenang Kota
Manado Tahun 2014, Jurnal Medika Kesehatan, Februari 2015, Vol 3 No 1.

BPOM, 2014, Grafik Kasus Keracunan Nasional Yang Terjadi DI Tahun 2014 Berdasarkan Kelompok Penyebab, Jakarta.

Departemen Kesehatan RI, 2002, Syarat-Syarat dan Pengawasan Kualitas Air Minum, PERMENKES $\mathrm{NO}$ 907/MENKES/SK/VII/2002.

Departemen Kesehatan RI, 2005, Info Penyehatan Air dan Sanitasi Vol VII, No. 13, Percetakan Negara, Jakarta.

Departemen Kesehatan RI, 2010, Peraturan Menteri Kesehatan No 492 Tahun 2010 tentang Persyaratan Kualitas Air Minum.

Departemen Perindustrian dan Perdagangan RI, 2004, Keputusan Menteri Perindustrian dan Perdagangan No 651 Tahun 2004 tentang Persyaratan Teknis Depot Air Minum dan Perdagangannya.

Efri Malisa Dwi Putri, 2015, Hubungan Higiene Sanitasi dengan Kontaminasi Bakteri Coliform Pada Air Minum Isi Ulang di Kecamatan Seberang Ulu 1 Kota Palembang Tahun 2015, Skripsi, Jakarta: Program Studi Kesehatan Masyarakat Fakultas Kedokteran dan Ilmu Kesehatan Universitas Islam Negeri Syarif Hidayatullah Jakarta. 106 hal.

Kementerian Kesehatan RI, 2010, Peraturan Menteri Kesehatan RI Nomor 736/MENKES/PER/VI/2010 tentang Tata Laksana Pengawasan Kualitas Air Minum, 25 hal.

Kementerian Perindustrian dan Perdagangan RI, 1997, Keputusan Menteri Perindustrian dan Perdagangan RI Nomor 167/MPP/Kep/5/1997/ tentang Persyaratan Teknis Industri dan Perdagangan Air Minum dalam Kemasan, 49 hal.

Keputusan Menteri Perindustrian dan Perdagangan Republik Indonesia, 2004, Persyaratan Teknis Depot Air Minum dan Perdagangannya. Menteri Perindustrian dan Perdangan Republik Indonesia, 16 hal.

Muhammad Mavis Mirza, 2014, Hygiene Sanitasi dan Jumlah Coliform Air Minum, Jurnal Kesehatan Masyarakat, Pusat Layanan Kesehatan Unnes, Semarang. 
Peraturan Menteri Kesehatan Reprublik Indonesia, 2010, Persyaratan Kualitas Air Minum, Menteri Kesehatan republik Indonesia, 9 hal.

Peraturan Menteri Kesehatan Republik Indonesia, 2014, Higiene Sanitasi Depot Air Minum, Menteri Kesehatan Republik Indonesia, 26 hal.

Rahayu, CS. Setiani, O \& Nurjazuli, N. 2013. Faktor Risiko Pencemaran Mikrobiologi pada Air Minum Isi Ulang di Kabupaten Tegal. Jurnal Kesehatan Lingkungan Indonesia.Vol 12 No. 1/April 2013

http:// ejournal.undip.ac.id/index.php/jkli/article/vie w/5954.

SNI, 2006, Air Minum Dalam Kemasan, Standar Nasional Indonesia, SNI 01-3553-2006, Badan Standar Nasional.

Supriyono Aswafi, 2004, Analisis Faktor yang Berhubungan dengan Kualitas Mikrobiologis Air Minum Isi Ulang di tingkat Produsen di Kota Semarang, Tesis, Magister Kesehatan Lingkungan, Semarang, Program Studi Pasca Sarjana Universitas Diponegoro. 